\title{
A Tracer Study of Fashion Design Education Program at State University of Surabaya
}

\author{
Irma Russanti \\ Home Economics Department \\ Universitas Negeri Surabaya \\ Surabaya, Indonesia \\ irmarussanti@unesa.ac.id
}

\begin{abstract}
In accordance with developing curriculum, it is necessary to conduct a tracer study at fashion design education program, Universitas Negeri Surabaya. This study focuses on the profiles of the graduates programs, the relevance between graduates' jobs with their academic backgrounds, and the satisfaction of company that employs the graduates. Under descriptive concepts study, this study uses 194 subjects who graduated between 2009-2013 periods. The data was from relevant documents such as graduation documents had by Engineering Faculty, alumnae documents and graduation books in 2009-2013 periods. Moreover, questionnaires and interviews are also conducted to support the data collection. The results of this study found that 1) the graduates' profiles of this study program are: $75.5 \%$ of graduates have got their jobs in less than 6 months in which $58 \%$ of them get from their peers while the rests of them get from the job vacancy advertisement, and 55\% of the subjects obtain IDR 1.5-3 million as their first salary; 2) 95\% of graduates state that their academic backgrounds are relevant to their current jobs, and, commonly, they are sure that their academic backgrounds are helpful when they are at working fields; 3) there are $39 \%$ of satisfied companies who state that the graduates' working performances are very good, while others are good for $36 \%$ and enough for $24 \%$.
\end{abstract}

Keywords- tracer study, fashion design education, graduates, employers

\section{INTRODUCTION}

Fashion Design Education Program is one of study programs had by Home Economic Major, Engineering Faculty at State University of Surabaya. In case of developing a study program which is based on curriculum, it is important to possess basic construction of curriculum that further to be used to direct the development process of intended curriculum relevantly to the institution's vision and mission and as also to the national education goals. Moreover, this basic scaffolding can be used as a reference in solving any problems that may occur within the development process and to be an academic quality assurance at State University of Surabaya.

There are several steps in developing the above-intended curriculum. They are namely need assessment study, feasibility study, exchange and benchmarking, evaluation to the ongoing programs, tracer study, evaluation to the ongoing curriculum, designing new curriculum, validation and revision, public trial, sanctioning the result of developing, implementing, and evaluating curriculum. In connection to those steps, it is necessary to involve whole stakeholders, including but not limited to professionals, alumnae, related government sectors, and other relevant parties. This developing curriculum program aims at improving the competence of graduates in accordance with the employment necessities. This development is done by conducting curriculum revision.

Curriculum revision aims to enhance education quality. In this case, Fashion Design Education Program does curriculum revision referring to IT development and demands at working field. The source of data to improve the graduates' competence is tracer study which is conducted to the graduates and the companies or institutions that employ the graduates. Tracer study is a study of graduates in higher education institution. Another name of tracer study is graduate surveys, alumnae researches and follow-up study [1]. Tracer study can provide information for the sake of evaluating the performance of higher education institution that further can be used to perfecting and guarantying education quality also evaluating the result [2] and determine the success of the education and training process that has been done toward their students [3] of in such institution. Besides, tracer study also provides valuable information related to the relationship of higher education and professionalism at working field, assesses the relevance between higher education institution and other relevantly supported stakeholders, gives information to them, and becomes a prerequisite of higher education accreditation.

In addition, tracer study also becomes one of ways to gather information related to the transition between graduation times and the times to be employed. In accordance with that, it needs the compliment-able stakeholders including the graduates, the institution where the graduates previously studied, and the company or institution where the graduates work. It can be conducted in diverse ways, including but not limited to the use of questionnaires which are distributed manually or massively in online and interviews which can also be in forms of written in online according to the needs, occasions and context. It is a form of empirical study to evaluate results of higher education institution. By compiling and combining certain basic components namely the level of graduates, job vacancy, working possibility (includes working experience and skills and interests) it is expected to portray the weakness possibility of the given education program and help to plan better revision either in institutional or national levels. Thus, the academic quality possessed by the graduates can be in line and supporting the economic necessities.

Tracer study as an assessment instrument to trace back to particular elements of certain group in order to determine whether something is effective or not [4]. Tracer study may 
be used to analyze the relationship between higher education and the occupation [1]. Besides, the documentations of graduates help to improve a certain institution in case of professionalism and competence. Tracer study helps to accelerate professionalism, disciplinary, education level, jobs characteristics obtained by graduates, competence and skill development, and comparative analysis in which all is also essential to develop curriculum and revolution [4]. This type of study is conducted worldwide in Europe, Asia and America; it also has been conducted in some registered parts of African Association [5].

In connection to above importance of conducting such study, this study aims at the same objectives namely improving education quality by developing revised curriculum which is conducted as relevant steps in Fashion Design Education Program at State University of Surabaya. This study includes graduated subjects from 2009 to 2013 periods to obtain the information by employing questionnaires, interviews and discussion forums between Fashion Design Education officers, alumnae and other relevant stakeholders. Those obtained data are used to answer three research questions; how the profiles of graduates of Fashion Design Education Program are investigated based on times to get a job, source of getting a job, times where graduates start to search for a job, kinds of a job possessed, and the salary got by graduates, 2) how relevant academic background with the possessed jobs is, and 3) how satisfied the company or institution which employ the graduates are.

\section{METHOD}

This study used the survey research method [6] to evaluative approach to investigate the profiles of graduates, the relevance of academic background and the job, and the satisfaction of company or institution where graduates work. Descriptive study is purposed to describe a phenomenon by observing and portraying it. It is done without involving in both internal and external influential factors into scientific writing [7]. The descriptive evaluative purposes to describe particular phenomenon but then make the results as evaluation to certain regulations or roles [8]. There are 194 random samples of 224 total respondents graduated from Fashion Design Education Program at State University of Surabaya from year 2009 to 2013 periods which are used as the subjects of this study.

The development of instruments for this study is based on the academic scripts of curriculum development at study programs had by State University of Surabaya in 2015. The variables include; A) profiles of graduates and the relevance between courses and teaching and learning activities in which this later acts as instrument to reveal the first and second research question and B) company or institution that employ the graduates, and the responds to the graduates' working performances. The application of questionnaires and relevant interviews was done through online practices in social media, or call. In the surveys, respondents have to give their respond of 30 questions in questionnaires that are described as follows:
TABLE I. QUESTIONNAIRE CONTENTS

\begin{tabular}{|c|c|}
\hline Points & Components \\
\hline Profiles of graduates & $\begin{array}{l}\text { a. Times to wait the employment } \\
\text { b. Source of employment information } \\
\text { c. Times to search jobs after the } \\
\text { graduation } \\
\text { d. Types of jobs had by the graduates } \\
\text { e. First salary amount }\end{array}$ \\
\hline $\begin{array}{l}\text { The relevance between } \\
\text { academic backgrounds } \\
\text { and the job possessed } \\
\text { by the graduates }\end{array}$ & $\begin{array}{l}\text { a. Relevance between skills and the job } \\
\text { b. The appropriateness of materials to } \\
\text { be used by the graduates } \\
\text { c. The Benefits of PI or PKL program } \\
\text { (or known as internship program) } \\
\text { d. The appropriateness of courses } \\
\text { contents with graduates' current jobs } \\
\text { e. The relevance between practical } \\
\text { course with the jobs } \\
\text { f. The quality of teaching and learning } \\
\text { process }\end{array}$ \\
\hline $\begin{array}{l}\text { The satisfactory level } \\
\text { given by companies } \\
\text { where graduates work }\end{array}$ & $\begin{array}{ll}\text { a. } & \text { Integrity (moral ethics) } \\
\text { b. } & \text { Professionalism } \\
\text { c. } & \text { English proficiency } \\
\text { d. } & \text { IT usage } \\
\text { e. } & \text { Communication } \\
\text { f. } & \text { Team work } \\
\text { g. } & \text { Self-development }\end{array}$ \\
\hline
\end{tabular}

The procedures of conducting this study include; 1) direct documentation of graduation documents and books, 2) direct visitation to where the graduates/alumnae work, 3) direct documentation of graduates' strengths and weaknesses from the place where graduates work, 4) Arrangement of questionnaires and interviews, 5) identification of education institution or the company where graduates work, 6) determining education institution and also other related work fields, 7) direct visitation at where graduates work, 8) interview done with the graduates/alumnae via call, 9) question and answer session in social media (Facebook), 10) sending the instrument to the graduates' mail and Face book message, 11) data collection, 12) data analysis, and 13) composing tracer study.

This data analysis uses descriptive percentages [9] to portray the survey results that have been fulfilled by the respondents and the company or education institution representatives by using the following formula:

$$
\%=\frac{n}{N} \times 100 \%
$$

\section{NB:}

$\%=$ Descriptive percentage of the conducted tracer study

$\mathrm{n}=$ value got by multiplying scores of each point in questionnaires with the total score

$\mathrm{N}=$ total score got by multiplying total sample with total items

\section{RESULT AND DISCUSSION}

Based on the data gained through surveys, more than 229 alumnae graduated in 2009 to 2013 , only $84.7 \%$ of them, about 194 respondents, completed the questionnaires. Since the obtained data is more than $75 \%$, the data can be used in this tracer study. 


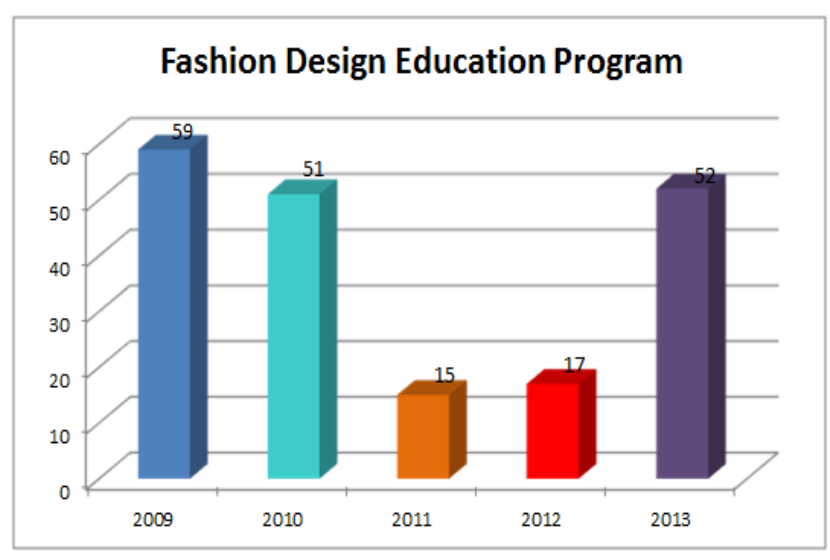

Fig. 1 Total graduates in 2009 to 2013

In accordance with Figure 1, there were 59 graduates in 2009, 51 graduates in 2010, 15 graduates in 2011, 17 graduates in 2012, and 52 graduates in 2013. These graduates as respondents provided diverse results of graduates' profiles, gave different perspectives related to the connection between skills and graduates' jobs, and did various impressions to companies or institutions where they are being employed.

\section{A. Profiles of Graduates}

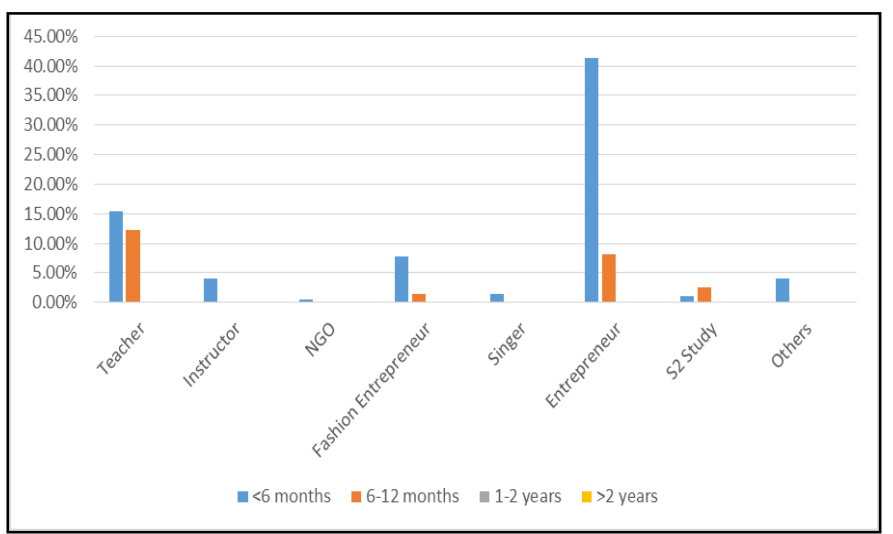

Fig. 2 Times for graduates to be employed

Fig. 2 shows the times for graduates to be employed in either education institutions, companies, or private entrepreneur. First, Figure 2 shows that the average of waiting times done by graduates to get their first jobs is relatively less than 6 months that had been responded by $75.5 \%$ of samples. There are several jobs possessed by the graduates which can be derived from $75.5 \%$ into; 1) $19.5 \%$ of graduates works at educational institution consisting of $15.5 \%$ of them as teachers and $4 \%$ of them as instructors, 2) $49 \%$ of graduates does not engage in the education field which can be divided into $7.7 \%$ of them as fashion entrepreneur, $41.3 \%$ of them as entrepreneur, and the rests of them as pattern maker, production planner and designer, and 3 ) $8.5 \%$ of the graduates work diversely such as $0.5 \%$ of them involves in NGOs, $1.5 \%$ of them as singer, $1 \%$ of them as students of Master Program, and $4 \%$ of them are having the other jobs. Second, Figure 2 also shows that $24.5 \%$ of respondents state that they had had to wait for 6 up to 12 months to get employed as teachers, fashion entrepreneurs, entrepreneurs and Master students.

Further, it is necessary to trace the sources where the graduates got the employment information. There are some sources obtained by the graduates to be employed; $58 \%$ of them get the information from their friends, $26 \%$ of them get from the company, and the other $4 \%$ is from family and self-searching. However, the sources are not easily to get, or in other words, graduates need times to search the job sources. There are various waiting times to get the jobs. To cope with that, $42 \%$ of the graduates of Fashion Design Education Program get the jobs right after the graduation. Surprisingly, $26 \%$ of the respondents get the jobs even before the graduation. This number represents that they have eagerness in searching jobs. Unfortunately, even the number is quite insignificant, there are still $4 \%$ of graduates need to wait longer for the employment, and the other $4 \%$ has no information yet.

Fig. 3 shows how graduates diversely get types of jobs. It also exhibits that graduates of Fashion Design Education Program at State University of Surabaya are interested to be entrepreneur. This is due to the enough modal of money got by the graduates when they were in undergraduate program. Moreover, being fashion or other types of entrepreneur makes them independent and good for actualizing the experience during the study times. For instance, it can be seen that there is an increase number of being either fashion or other types of entrepreneur starting from 5\% in 2009 until $11 \%$ in 2013. The second most intended job is being an entrepreneur, then followed by being instructors, Master students, and so on.

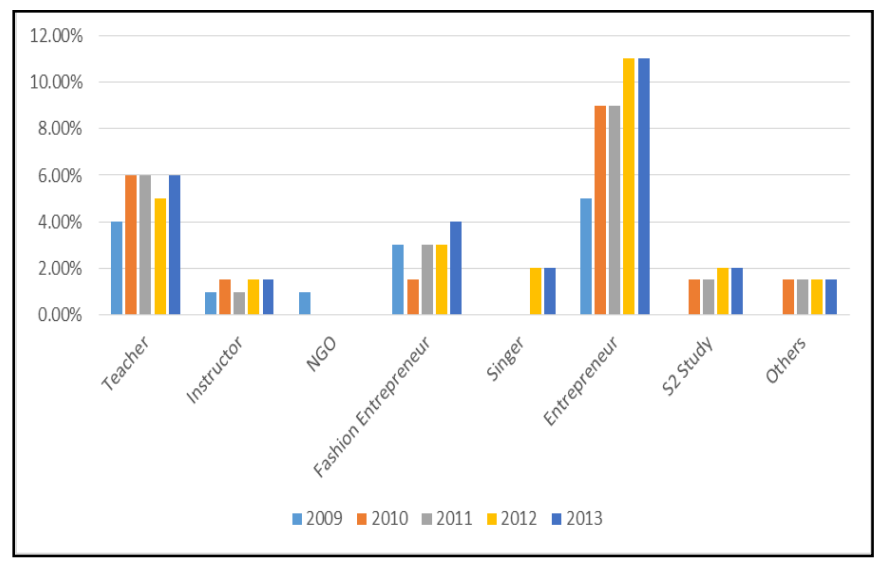

Fig. 3 Types of first jobs based on Graduation Periods

Based on portrayed various jobs above, graduates get different salary amounts in their first employment. 55\% of graduates who work as entrepreneurs get the highest salary compared to other jobs for about IDR 1.5-3 million in a month. The second highest salary has got by a fashion entrepreneur, which is about $29 \%$ of the respondents, they will get about IDR 1-1.5 million in a month, and the rests are IDR 750,000 up to 1 million as vocational instructors and IDR 300,000 as honorary teachers.

\section{B. The Relevance between Academic Backgrounds and Jobs}

Based on the investigation which has done to 194 respondents, $95 \%$ of them state that they have jobs which 
are relevant to their skills. This number also conveys that $95 \%$ of graduates portrays that their competence supports their professionalism. Moreover, they state that during study times, they experienced pedagogic skills, attitudes in fashion enterprises, and entrepreneurship. Only $5 \%$ of them feel that the jobs they possess are irrelevant to the competence they pursued along undergraduate study times. It can be said that the majority works is in accordance to the competence or skills they learned during study times.

For those who are doing activity like teachers, it is also necessary to investigate the relevance materials that graduates got during study times and the materials that they teach when they become teachers. $83 \%$ of the graduates who become teachers state that materials learnt during their undergraduate study times relevantly support them in their current jobs. The rest of $17 \%$ believes that there is no relevance between materials they got during study times and the materials they teach at school. Thus, even the majority respondents state that the materials are relevant; there must be trace back to review why $17 \%$ of them feel irrelevant.

To understand the deeper materials discussed above, it is essential to trace back into theoretical, practical, and internship materials. First, there are $84 \%$ of the graduates stating that the theoretical materials are relevant with their current jobs, while $16 \%$ does not think so. Second, $73 \%$ of respondents argue that practical materials are relevant to their current jobs in which this number shows that practical materials support graduates' competence when they are at work fields. However, $27 \%$ of respondents state that the irrelevance happens between practical materials and their current jobs. The last is there are $74 \%$ of the graduates who feel the benefits of internship program. Even though this internship program covers the application of management concept and skills in various fashion industries/companies, there are $26 \%$ of the graduates still do not feel the benefits of this program in their current jobs. By seeing above numbers, the majority of graduates of Fashion Design Education Program feel the relevance between materials they learned during study times and the situation where they currently work.

\section{The Employers' Satisfaction about Graduates' Working Performances}

This satisfactory feedback can be investigated through the results of employability responses. Employability is a foundation skill needed to get, to defend, and to conduct a job well in which skills, attitudes, and behaviors are included within it. Based on the trace investigation to the company, institution, or other work places, there are seven important elements to reveal whether the company, institution, or work places where the graduates work feel satisfied about graduates' working performances; moral ethics, professionalism, English competency, IT mastery, communication skill, team work, and self-development.

Based on such investigation, it is found that first, $51 \%$ of the employers state that the graduates' working performance in relation with moral and ethical point is excellent, while $33 \%$ state as good, and the others are diverse. This number shows that employers are satisfied enough to graduates' moral and ethical performances. Second, $40 \%$ of employers states that graduates' professionalism is very good, while $33 \%$ is good, and the rests are enough. Since the numbers are not widely distinct, this data indicates that professionalism is a serious matter to be handled in order to enhance the graduates' professionalism quality. Third, there are $42 \%$ of the employers who state that graduates' English competence is not satisfied, while $25 \%$ is very good and others are good. This indicates that there must be curriculum ratification at Fashion Design Education Program in connection to entrepreneurship education [10] and English course. Fourth, there are $42 \%$ of employers who states that graduates' IT mastery is excellent, $44 \%$ is good, and the rests are not satisfied enough. This number shows that graduates' IT mastery is in above average. Fifth, in certain jobs that require communication skills, there are $45 \%$ of employers feel that graduates' communication skills are very good, while $30 \%$ is good, and $25 \%$ is enough. Sixth, $56 \%$ of employers state that graduates' working performance related to team work is very good. This number is indeed above average and can be classified as excellent performance. At last, there are $33 \%$ of employers who feel that graduates' self-development is very good, good, and enough respectively. Thus, Fig. 4 shows the average of satisfactory level given by employers where graduates currently work.

\section{Employers' Satisfactions}

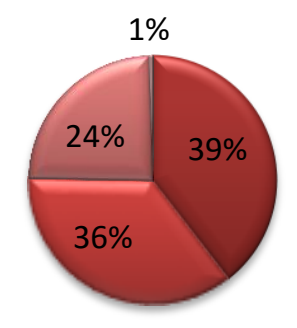

Q Very gooı

$\square \operatorname{good}$

$\square$ Average

$\square$ Bad

Fig. 4 Employers' Satisfactory Level

Fig. 4 shows that $39 \%$ of employers feel satisfied to graduates' working performance by stating in very good level. In other sides, $36 \%$ of them states in good level to convey graduates' working performance. For the average level, there are $24 \%$ of employers included in this category. In addition, there are only $1 \%$ of unsatisfied employers to the graduates' working performance. In other words, it can be said that only $1 \%$ of employers who feel that graduates do not meet the seven elements of working performance criteria.

\section{CONCLUSIONS}

Based on this tracer study, it can be found that (1) the majority of graduates becomes fashion designer or other types of entrepreneurs with the salary which range from IDR 1.5 up to 3 million. The numbers of being entrepreneurs increased during 2009-2013 periods. They get that job in less than 6 months where $58 \%$ of them get the vacancy information from their friends. Moreover, the majority gets the first jobs just right after the graduation. However, there are also the rests who must wait 1 up to 2 years to get employed. (2) Majority of graduates feel the relevance between materials they learned through 4 years study times and the jobs' competences they have. For instance, $95 \%$ of the graduates show the relevance between skills they learned with the jobs and $83 \%$ of them show the relevance between whole courses and the jobs. (3) There are 
$75 \%$ of employers feels satisfied of graduates' working performance while only $25 \%$ of them shows unsatisfied.

\section{ACKNOWLEDGMENT}

I would like to thank to Fashion Design Education Program at Universitas Negeri Surabaya that gives me opportunity to conduct this study. I also send my honor to supportive parties that help me in composing this final paper. Last but not the least, I would like to thank to every constructive feedbacks given by any parties.

\section{REFERENCES}

[1]. Schomburg, herald, 2013, Handbook for Tracer Study, Centre for Research on Higher Education and Work, University of Kassel

[2]. Aquino, B.Anania, 2015, Teacher Education Graduate Tracer Study from 2010 to 2014 in One State University in Batangas, Philippines, Asia Pacific Journal, Multidisciplinary Research Vol. 3 No. 5 December 2015 Part II.

[3]. Reny, Etc, 2013, Exploring Tracer Study Service in Career Center Web Site of Indonesia Higher Education, International Journal of Computer Science and Information Security Vol. 11 No. 3 March.

[4]. Gines, Adelaida C., 2014,Tracer Study of PNU Graduates, American International Journal of Contemporary Research Vol. 4 No. 3; March 2014.

[5]. Chaudhary, Neelam and Shankar, 2016, A Tracer Study Of Ignou Graduates, International Journal of Current Advanced Research Vol 5, Issue 4, pp 791-798, April 2016

[6]. Fronda, Flordeliza P., and Villanueva Fe Corazon, 2015, Tracer Study of Emplyment of BSHRM Graduates of The LA Consolacion Universitu Phillppines from 2011-2013, Journal of Sciences and Humanities Research, 1(2).1-6.

[7]. Shuttlewort, M, 2008, Descriptive Research Design - Observing a Phenomenon, url: http://explorable.com/descriptive-research-design, date retrieved: Maret 21, 2017

[8]. Dotong, Conrado I., Etc, 2016, Tracer Study Of Engineering Graduates Of One Higher Education Institution In The Philippines For Academic Year 2009-2012, European Journal Of Engineering And Technology Vol. 4 No. 4, 2016 Issn 2056-5860

[9]. Rojas. T, Rojas. R, 2016, College of Education Graduate Tracer Study (GTS): Boon or Bane?, European Scientific Journal June 2016 edition Vol. 12 No. 16. ISSN: 1857-7881.

[10]. Ocampo, Melani B., Etc, 2012, Culture of Entrepreneurship versus Employment, Fifth Taiwan Philippines Academic Conference: Digital Humanities and Cultural Studies. 